\title{
ANALISIS BATIMETRI SUNGAI SERANG UNTUK MENDUKUNG PENGEMBANGAN INFRASTRUKTUR YOGYAKARTA
}

\author{
Hilmiyati Ulinnuha ${ }^{1}$, Maritsa Faridatunnisa ${ }^{2}$, Abdul Basith ${ }^{3}$ \\ 1,2,3Departemen Teknik Geodesi, Fakultas Teknik, Universitas Gadjah Mada; Jalan Grafika No.2 Sleman Yogyakarta, \\ (+62274) 520226 \\ e-mail: ${ }^{1}$ hilmiyatiulinnuha01@ugm.ac.id
}

\begin{abstract}
Abstrak
Salah satu kriteria infrastruktur yang baik adalah adanya connecting jalur transportasi darat, laut, maupun udara. Untuk mendukung infrastruktur yang baik di Yogyakarta, diperlukan pengembangan pelabuhan Tanjung Adikarto yang terletak saling berdekatan dengan Bandara New Yogyakarta International Airport. Alih-alih memiliki infrastruktur Pelabuhan yang baik, Pelabuhan Tanjung Adikarto mengalami sedimentasi karena pengaruh berbagai hal. Salah satu faktor yang dapat menyebabkan sedimentasi Pelabuhan Tanjung Adikarto adalah sedimen yang terbawa oleh Sungai Serang. Oleh karena itu, penelitian ini bertujuan untuk menganalisis batimetri Sungai Serang dan menginterpolasi lokasi sedimentasi Sungai Serang.

Metode analisis batimetri yang digunakan dalam penelitian adalah menguji ketelitian data pengukuran kedalaman dan menginterpolasi lokasi sedimentasi berdasarkan profil melintang dan memanjang Sungai Serang. Selain itu, juga dilakukan analisis data pasang surut air Sungai Serang dan mengevaluasi masalah pengembangan di Pelabuhan Tanjung Adikarto.

Hasil penelitian ini menunjukkan bahwa pasang surut laut masih mempengaruhi dinamika Sungai Serang hingga sekitar $1 \mathrm{~km}$ dari area breakwater Pelabuhan Tanjung Adikarto. Sesuai standar IHO, data kedalaman pengukuran Sungai Serang masuk dalam Orde 1, sedangkan lokasi sedimentasi berada di area tepi sungai dan disekitar pintu masuk Pelabuhan Tanjung Adikarto. Untuk pengembangan infrastruktur, masalah sedimentasi Pelabuhan Tanjung Adikarto dapat disebabkan oleh kondisi breakwater. Namun, hal ini masih memerlukan kajian lebih lanjut.
\end{abstract}

Kata kunci: single beam echosounder, batimetri, sungai, infrastruktur, kedalaman

\begin{abstract}
One criteria of a good infrastructure is to connect land, sea, and air transportation routes. To support good infrastructure in Yogyakarta, the development of Tanjung Adikarto port, located close to New Yogyakarta International Airport, is needed. Instead of having a good port infrastructure, Tanjung Adikarto Port experience sedimentation due to various factors. One of them is sediment carried by Serang River. Therefore, this study aims to analyze Serang River bathymetry and interpolate location of sedimentation in Serang River. The method of bathymetry analysis used is by testing the accuracy of the depth measurement data and interpolate the sedimentation location based on the transverse and longitudinal profile of the Serang River. In addition, Serang River tidal data analysis was also carried out and development problems in Tanjung Adikarto Port is also evaluated.

The results of this study indicate that the tides still affect the dynamics of the Serang River up to about $1 \mathrm{~km}$ from the Tanjung Adikarto Port breakwater area. According to IHO standards, Serang River depth measurement data classified as Order 1, while sedimentation occur in the river bank area and around the entrance of Tanjung Adikarto Port. As for infrastructure development problem, Tanjung Adikarto Port sedimentation problem might be caused by breakwater conditions. However, this may requires further study.
\end{abstract}

Keywords: single beam echosounder, bathymetry, river, infrastructure, depth 


\section{PENDAHULUAN}

Pengembangan infrastruktur hendaknya mempertimbangkan aspek integrasi setiap unsurnya, terlebih mengenai infrastruktur transportasi. Provinsi Daerah Istimewa Yogyakarta (DIY) saat ini sedang dalam proses pembangunan Bandara Internasional Yogyakarta yang letaknya berdekatan dengan Pelabuhan Tanjung Adikarto. Kedua infrastruktur ini berada di Kecamatan Wates, Kabupaten Kulon Progo, Provinsi DIY. Meskipun demikian, Pelabuhan Tanjung Adikarto masih belum dapat beroperasi karena pendangkalan akibat sedimen yang berpindah dan mengendap.

Sedimentasi yang terjadi di Pelabuhan Tanjung Adikarto diduga berasal tidak hanya dari Pantai Selatan, namun juga Sungai Serang yang berada di sebelah barat pelabuhan. Oleh karena itu, penelitian ini membahas mengenai analisis profil kedalaman Sungai Serang yang diduga memengaruhi pendangkalan di Pelabuhan Tanjung Adikarto. Hasil penelitian ini diharapkan mampu memberi pengetahuan mengenai hubungan kondisi Sungai Serang dan Pelabuhan Tanjung Adikarto.

Kegiatan pengukuran hidrografi dan pemantauan sedimen telah dilakukan oleh peneliti sebelumnya diberbagai lokasi. Pengukuran data batimetri serta detail morfologi seabed menggunakan multibeam echosounder telah dilakukan (Yuwono, Pratomo, \& Al-Azhar, 2018) dalam analisis keselamatan alur pelayaran di bagian barat Surabaya. Evaluasi kondisi dermaga di perairan Cilacap juga telah dilakukan dengan melakukan simulasi numerik dengan persamaan hidrodinamika sehingga diperoleh pola arus dan distribusi sedimen di perairan tersebut (Pratomo, Froditus, \& Pribadi, 2019).

Selain itu, analisis pola sebaran sedimen untuk pemeliharaan kedalaman perairan di pelabuhan Tanjung Perak juga telah dilakukan oleh Pratomo dkk dengan menggunakan perangkat lunak Delft3D untuk memperoleh pemodelan arus dan sebaran sedimen (Pratomo, Hutanti, \& Khomsin, 2019). Analisis pendangkalan di pelabuhan minyak juga telah dibahas baik di pelabuhan minyak PT Caltex Pacific Indonesia, Dumai, Riau pasca pengerukan tahun 1990 (Siry, 2011). Kegiatan ini melakukan pengamatan arah dan kecepatan arus, pasang surut, kedalaman, tingkat keasaman perairan, tinggi dan periode gelombang pada 18 stasiun, serta pengamatan gravimetris untuk menghitung berat dan jenis fraksi dari sampel sedimen. Analisis sedimentasi juga dilakukan di kolam pelabuhan Jetty Pertamina Balongan, Indramayu oleh (Arifin \& Rachmat, 2011). Pengamatan yang dilakukan meliputi arus stasioner, trayektori arus, pasang surut dan hindcasting gelombang.

Perhitungan sedimentasi pun dapat dilakukan dengan beberapa metode. Salah satunya dilakukan dengan perhitungan sedimentasi dari data Digital Terrain Model (DTM) kedalaman di Waduk Sermo (Cahyono, 2015). Selain itu, juga dapat menggunakan metode pendekatan usle dan pengukuran kandungan tanah dalam air sungai sehingga diperoleh volume sedimentasi Waduk Sermo (Cahyono, 2017).

Studi mengenai pola arus dan sedimentasi di dekat breakwater bagian luar kolam labuh pelabuhan Tanjung Emas Semarang telah dilakukan oleh (Febribusmadian, Purwanto, \& Hariadi, 2012). Pengamatan dilakukan pada arus dari ADCP dan data sedimen dasar di luar kolam Pelabuhan Tanjung Emas. Selain itu, data pasang surut keluaran BMKG dan data prediksi pasang surut dari Dishidros, peta batimetri perairan Semarang skala 1:50.000 dan peta RBI dengan skala 1:25.000 juga digunakan. Hasil analisis menemukan bahwa ada hubungan antara pola arus dengan ukuran butiran sedimen yang diendapkan.

Unmanned Surfave Vehicle (USV) adalah kapal kecil yang dapat dikendalikan otomatis. USV digunakan sebagai salah satu wahana survei, inspeksi lingkungan sungai, seismic, maupun penyelamatan. Tahun 2009, telah dilakukan penelitian pemantauan kualitas air oleh (Dunbabin, 2009). Salah satu hasil penelitian adalah terbukti USV mampu melewati air pedalaman yang kompleks. Selain USV, pengukuran hidrografi juga dapat menggunakan single beam echosounder, multi beam echosounder, dan ekstraksi dari citra satelit resolusi tinggi.

Berbagai studi pustaka yang telah dilakukan memberikan gambaran mengenai metode yang bisa digunakan. Namun hingga saat ini belum pernah dilakukan analisis sedimentasi di Sungai Serang dengan menggunakan single beam echosounder dan data oseanografi. 


\section{METODE}

Metode yang digunakan dalam penelitian terdiri dari beberapa tahapan, yaitu persiapan, pengumpulan data batimetri dan oseanografi, pengolahan data, serta penyajian dan analisis hasil. Selanjutnya diuraikan metode pelaksanaan penelitian yang telah dilakukan.

\section{Persiapan}

Tahap awal dalam penelitian ini adalah dengan melakukan persiapan pengumpulan data. Persiapan yang dilakukan terdiri dari persiapan alat dan bahan, serta mempersiapkan perizinan yang diperlukan mengingat lokasi penelitian adalah di sekitar area Pelabuhan Tanjung Adikarto. Area pengukuran Sungai Serang ditunjukkan pada Gambar 1.

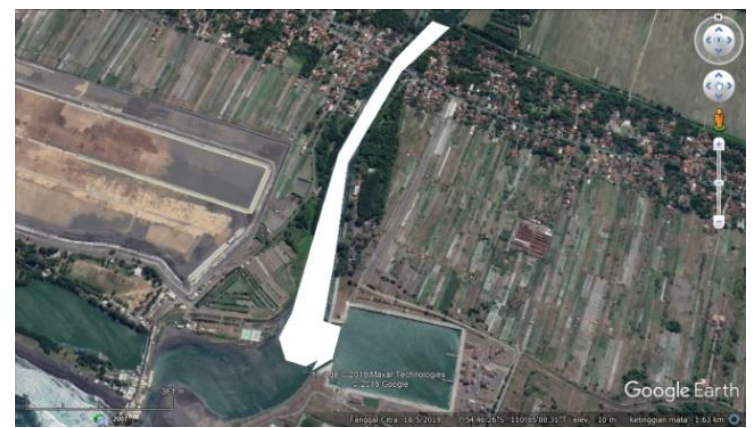

Gambar 1. Area Pengukuran Sungai Serang

\section{Pengumpulan Data Batimetri dan Oseanografi}

Proses pengumpulan data dilakukan selama satu hari pada tanggal 22 Juni 2019. Pengumpulan data terbagi menjadi dua fokus, yaitu pengumpulan data batimetri dan pengumpulan data oseanografi. Pengumpulan data batimetri dilakukan dengan menggunakan single beam echosounder. Gambaran pelaksanaan pengukuran ditunjukkan pada Gambar 3. s.d. 5.

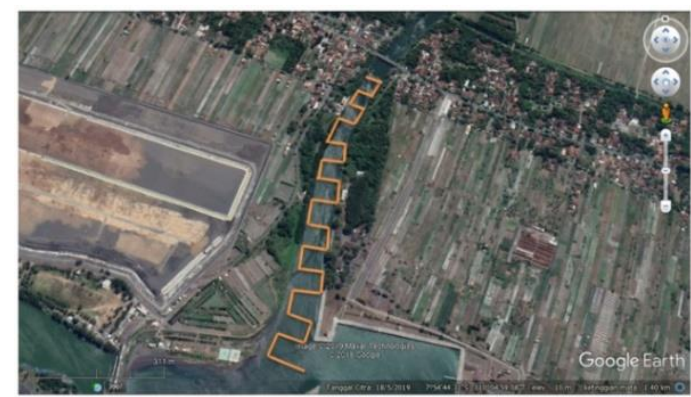

Gambar 2. Gambaran Desain Jalur Pengukuran Batimetri
Proses pengukuran batimetri dilakukan dengan desain jalur utama tegak lurus dengan arah arus. Arah arus Sungai Serang yaitu dari Utara ke Selatan, sedangkan arah lajur utama adalah Barat ke Timur. Selain lajur utama juga dilakukan pengukuran lajur silang dengan arah sejajar dengan arah arus Sungai Serang.

Untuk mendukung pengukuran batimetri diperlukan adanya pengukuran posisi horisontal. Pada penelitian ini digunakan teknologi GPS untuk penentuan posisi horisontal. Metode penentuan posisi horisontal yang digunakan adalah metode Real Time Kinematik (RTK) NTRIP. Metode ini menggunakan stasiun CORS terdekat sebagai reference station dan koreksi posisi diberikan melalui jaringan internet.

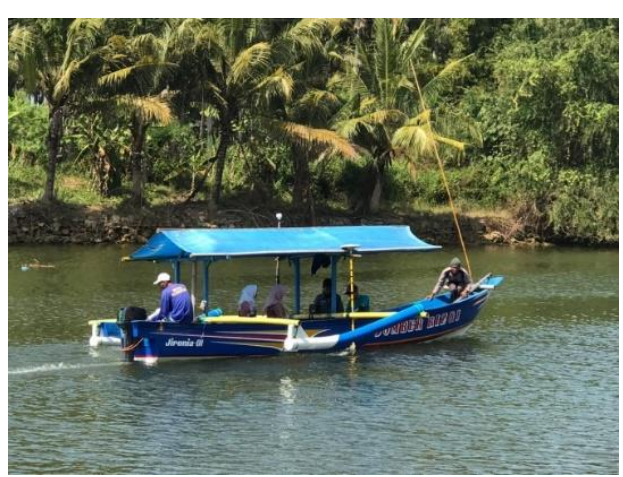

Gambar 3. Proses pengukuran batimetri

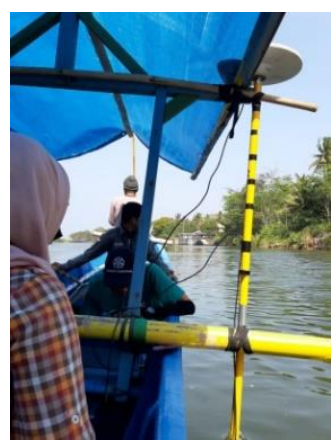

Gambar 4. Penggunaan GPS untuk Penentuan Posisi Horisontal

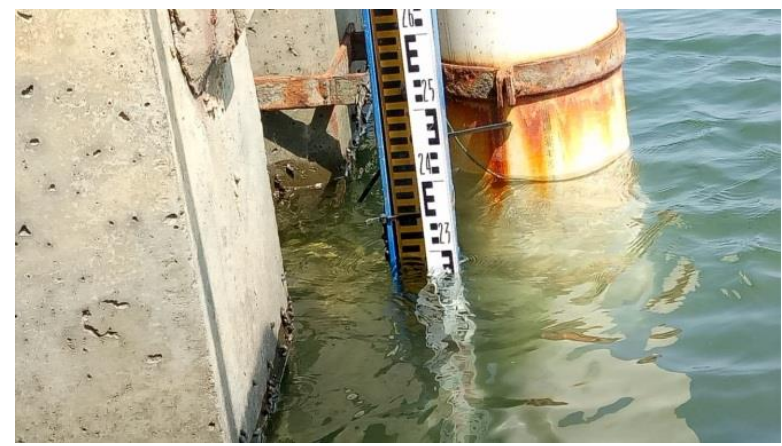

Gambar 5. Pengukuran Pasang Surut Laut 
Data oseanografi diperlukan untuk koreksi kedalaman air Sungai Serang terhadap fenomena pasang surut air laut. Data oseanografi ini dikumpulkan dengan pengamatan pasang surut air pada dua lokasi pengamatan. Pengukuran dilakukan dengan pembacaan rambu ukur yang dipasang pada titik pasang surut laut. Pembacaan tinggi rambu ukur dilakukan selama pengukuran batimetri berlangsung. Gambaran pelaksanaan pengukuran pasang surut ditunjukkan Gambar 5.

\section{Pengolahan Data}

Pengolahan data dilakukan dengan mengoreksi data kedalaman dengan beberapa koreksi, diantaranya yaitu koreksi draft kapal dan koreksi pasang surut. Setelah diberikan koreksi, selanjutnya dilakukan pembentukan Digital Terrain Model (DTM) dari profil kedalaman Sungai Serang. Posisi horisontal profil kedalaman menggunakan posisi dari pengukuran GPS, sedangkan data kedalaman didapatkan dari pengukuran single beam echosounder. Selain DTM Sungai Serang, juga dilakukan pembentukan profil melintang dan memanjang Sungai Serang. Proses terakhir dalam pengolahan data adalah menyajikan data kedalaman menjadi peta batimetri Sungai Serang tahun 2019.

\section{Analisis Batimetri Sungai Serang}

Proses analisis batimetri Sungai Serang menggunakan hasil ekstraksi profil melintang dan memanjang data kedalaman. Analisis ini bertujuan untuk mengetahui lokasi sedimen yang terbawa oleh Sungai Serang.

Untuk mengetahui kualitas data pengukuran, dilakukan uji ketelitian data pengukuran kedalaman Sungai Serang dengan menghitung nilai a dan $b$. Data yang diuji adalah data kedalaman yang dihasilkan dari lajur utama dan lajur silang. Uji ketelitian ini untuk menentukan orde yang dapat dicapai data pengukuran sesuai dengan aturan IHO Standards For Hydrographic Survey.

Toleransi kesalahan antara kedalaman titik lanjur utama dan lajur silang dihitung sesuai Persamaan 1 (SNI, 2010). Kesalahan pengukuran harus kurang dari tolerensi kesalahan yang dihitung.

\begin{tabular}{|c|c|c|c|c|c|}
\hline \multicolumn{4}{|c|}{$\begin{array}{l}\left. \pm \sqrt{a^{2}+(b x} d\right)^{2} \\
\text { alam hal ini, } \\
\text { : kesalahan independen } \\
\text { : faktor kesalahan dependen } \\
\text { : kedalaman terukur }\end{array}$} & \multicolumn{2}{|c|}{ (1) } \\
\hline \multicolumn{6}{|c|}{$\begin{array}{l}\text { Tabel 1. Ketelitian Pengukuran Parameter Survei } \\
\text { Hidrografi (IHO, 1998) }\end{array}$} \\
\hline No & Deskripsi & $\begin{array}{c}\text { Orde } \\
\text { Khusus }\end{array}$ & Orde 1 & Orde 2 & Orde 3 \\
\hline 1 & $\begin{array}{l}\text { Akurasi } \\
\text { horisontal }\end{array}$ & $2 \mathrm{~m}$ & $\begin{array}{c}5 m+5 \% \\
\text { kedalaman } \\
\text { rata2 }\end{array}$ & $\begin{array}{c}5 \mathrm{~m}+ \\
5 \% \\
\text { kedala } \\
\text { man } \\
\text { rata2 }\end{array}$ & $\begin{array}{c}5 \mathrm{~m}+ \\
5 \% \\
\text { kedala } \\
\text { man } \\
\text { rata2 }\end{array}$ \\
\hline 2 & $\begin{array}{l}\text { Alat bantu } \\
\text { navigasi } \\
\text { tetap dan } \\
\text { kenampakan } \\
\text { yang } \\
\text { berhubu } \\
\text { ngan dengan } \\
\text { navigasi } \\
\end{array}$ & $2 m$ & $2 \mathrm{~m}$ & $5 \mathrm{~m}$ & $5 \mathrm{~m}$ \\
\hline 3 & Garis pantai & $10 \mathrm{~m}$ & $20 \mathrm{~m}$ & $20 \mathrm{~m}$ & $20 \mathrm{~m}$ \\
\hline 4 & $\begin{array}{l}\text { Alat Bantu } \\
\text { navigasi } \\
\text { terapung }\end{array}$ & $10 \mathrm{~m}$ & $10 \mathrm{~m}$ & $20 \mathrm{~m}$ & $20 \mathrm{~m}$ \\
\hline 5 & $\begin{array}{l}\text { Kenampakan } \\
\text { Topografi }\end{array}$ & $10 \mathrm{~m}$ & $10 \mathrm{~m}$ & $20 \mathrm{~m}$ & $20 \mathrm{~m}$ \\
\hline 6 & $\begin{array}{l}\text { Akurasi } \\
\text { Kedalam an }\end{array}$ & $\begin{array}{c}a=0,25 \\
m \\
b= \\
0,0075 \mathrm{~m}\end{array}$ & $\begin{array}{c}a=0,5 m \\
b=0,013 \\
m\end{array}$ & $\begin{array}{c}a=1,0 \\
m \\
b= \\
0,023 \\
m\end{array}$ & $\begin{array}{c}a=1,0 \\
m \\
b= \\
0,023 \\
m\end{array}$ \\
\hline
\end{tabular}

Analisis Pengembangan Infrastruktur Yogyakarta Selain melakukan analisis terkait kedalaman Sungai Serang, penelitian ini juga melakukan analisis terkait pengembangan infrastruktur Yogyakarta. Analisis bertujuan untuk mengetahui peluangpeluang pengembangan area Pelabuhan Tanjung Adikarto berdasarkan informasi batimetri Sungai Serang.

\section{HASIL DAN PEMBAHASAN}

Hasil dari penelitian ini diuraikan menjadi beberapa bagian, yaitu hasil pengumpulan data oseanografi, hasil analisis tingkat presisi data batimetri, hasil analisis batimetri Sungai Serang, dan hasil analisis pengembangan infrastruktur Yogyakarta. Data oseanografi dianalisis untuk mengetahui pengaruh pasang surut air laut di Sungai Serang.

\section{Hasil Pengumpulan Data Oseanografi}

Pengukuran pasang surut (pasut) dilakukan pada 2 lokasi yang berbeda, yaitu di sekitar 500 meter dari 
breakwater dan di titik kurang lebih $1 \mathrm{~km}$ dari area breakwater. Gambaran lokasi pengukuran pasang surut laut ditunjukkan Gambar 6 .

Berdasarkan data hasil pengukuran, titik pasut memiliki ketinggian yang berbeda. Perbedaan ketinggian diantara kedua titik pasut dapat disebabkan oleh lokasi titik yang berbeda sehingga memiliki dasar dengan kedalaman yang berbeda pula.

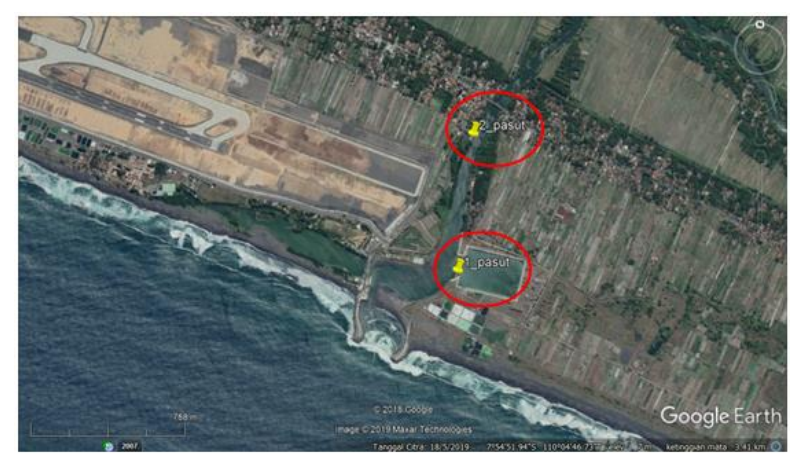

Gambar 6. Lokasi Titik Pengamatan Pasut

Dari pengukuran pasang surut laut di 2 lokasi yang berbeda tersebut, didapatkan hasil tinggi muka air yang memiliki trend yang sama. Hasil ketinggian pasang surut di lokasi 1 yaitu titik terdekat dengan breakwater masih dipengaruhi oleh pasang surut air laut di bibir pantai. Karena memiliki trend yang sama, maka dapat disimpulkan bahwa hingga jarak $1 \mathrm{~km}$ dari bibir pantai, ketinggian air Sungai Serang masih dipengaruhi oleh pasang surut air laut.

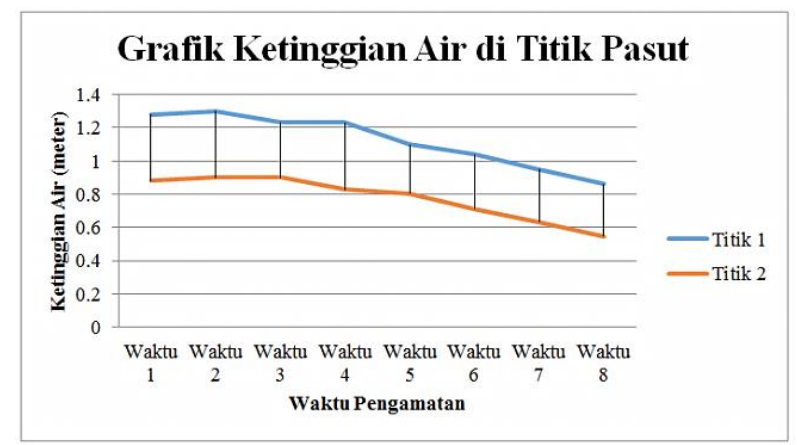

Gambar 7. Trend Hasil Pengamatan Pasut

Trend hasil data pasang surut pada dua lokasi titik pasut ditunjukkan pada Gambar 7. Kesamaan trend ini menyebabkan proses pengolahan data batimetri Sungai Serang tidak perlu dilakukan koreksi pasut secara terpisahpisah atau tidak perlu dibagi menjadi beberapa area karena terpengaruh oleh dinamika pasang surut air yang berbeda.

Berdasarkan Gambar 7., ketinggian air Sungai Serang memiliki trend menurun. Hal ini dapat disebabkan oleh tipe pasang surut di sekitar Pelabuhan. Data pasut diambil ketika tengah hari dan kondisi air memasuki fase surut air laut. Ketinggian air laut akan pasang lagi ketika memasuki sore hari.

\section{Hasil Analisis Ketelitian Data Pengukuran Kedalaman}

Tabel 2. Hasil Hitungan Data Kedalaman (meter)

\begin{tabular}{|c|c|c|c|c|c|}
\hline No & $\mathrm{LU}$ & LS & SELISIH & $S$ & $S^{2}$ \\
\hline 1 & 1,16 & 1,17 & $-0,01$ & 0,12 & 0,0144 \\
\hline 2 & 1,25 & 1,23 & 0,02 & 0,15 & 0,0225 \\
\hline 3 & 1,66 & 1,68 & $-0,02$ & 0,11 & 0,0121 \\
\hline 4 & 1,41 & 1,43 & $-0,02$ & 0,11 & 0,0121 \\
\hline 5 & 1,47 & 1,52 & $-0,05$ & 0,08 & 0,0064 \\
\hline 6 & 1,67 & 1,64 & 0,03 & 0,16 & 0,0256 \\
\hline 7 & 1,55 & 1,57 & $-0,02$ & 0,11 & 0,0121 \\
\hline 8 & 1,66 & 1,68 & $-0,02$ & 0,11 & 0,0121 \\
\hline 9 & 1,65 & 1,78 & $-0,13$ & 0 & 0 \\
\hline 10 & 1,87 & 1,86 & 0,01 & 0,14 & 0,0196 \\
\hline 11 & 1,83 & 1,9 & $-0,07$ & 0,06 & 0,0036 \\
\hline 12 & 1,9 & 1,87 & 0,03 & 0,16 & 0,0256 \\
\hline 13 & 1,99 & 1,94 & 0,05 & 0,18 & 0,0324 \\
\hline 14 & 2,1 & 2,01 & 0,09 & 0,22 & 0,0484 \\
\hline 15 & 2 & 2,03 & $-0,03$ & 0,1 & 0,01 \\
\hline 16 & 2,4 & 2,36 & 0,04 & 0,17 & 0,0289 \\
\hline 17 & 2,02 & 2,06 & $-0,04$ & 0,09 & 0,0081 \\
\hline 18 & 2,03 & 2,08 & $-0,05$ & 0,08 & 0,0064 \\
\hline 19 & 2,15 & 2,17 & $-0,02$ & 0,11 & 0,0121 \\
\hline 20 & 2,34 & 2,38 & $-0,04$ & 0,09 & 0,0081 \\
\hline 21 & 2,25 & 2,28 & $-0,03$ & 0,1 & 0,01 \\
\hline 22 & 2,36 & 2,25 & 0,11 & 0,24 & 0,0576 \\
\hline 23 & 1,84 & 2,02 & $-0,18$ & $-0,05$ & 0,0025 \\
\hline 24 & 2,58 & 2,4 & 0,18 & 0,31 & 0,0961 \\
\hline 25 & 2,49 & 2,45 & 0,04 & 0,17 & 0,0289 \\
\hline 26 & 1,61 & 1,6 & 0,01 & 0,14 & 0,0196 \\
\hline 27 & 4,47 & 4,4 & 0,07 & 0,2 & 0,04 \\
\hline 28 & 2,6 & 2,66 & $-0,06$ & 0,07 & 0,0049 \\
\hline 29 & 2,59 & 2,62 & $-0,03$ & 0,1 & 0,01 \\
\hline 30 & 1,26 & 1,25 & 0,01 & 0,14 & 0,0196 \\
\hline & \multirow{3}{*}{\multicolumn{2}{|c|}{$d$}} & $-0,13$ & SUM & 0,6097 \\
\hline & & & & Varian & 0,02032333 \\
\hline & & & & STD & 0,14255993 \\
\hline
\end{tabular}

Tabel 3. Hasil Uji Ketelitian Data Kedalaman (meter)

\begin{tabular}{l|r}
\hline $\mathrm{a}$ & 0,5 \\
$\mathrm{~b}$ & 0,013 \\
Kesalahan Pengukuran & 0,279 \\
Toleransi IHO & 0,5 \\
\hline
\end{tabular}

Data kedalaman yang digunakan dalam analisis ketelitian data pengukuran berjumlah 30 sampel titik. Sampel ini diambil dari lajur utama dan lajur 
silang. Hasil dari perhitungan ditunjukkan pada Tabel 2 dan 3.

Sesuai dengan standar IHO dan SNI Survei Hidrografi menggunakan single beam, survei di lokasi pelabuhan atau alur pendekat pelabuhan menggunakan daerah orde 1 (SNI, 2010). Oleh karena itu, nilai a dan $b$ pada perhitungan toleransi kesalahan menggunakan standar IHO pada orde 1. Berdasarkan Tabel 2. Dan 3., data kedalaman pengukuran Sungai Serang memiliki kesalahan pengukuran sebesar 0,279 meter dengan toleransi IHO sebesar 0,5 meter. Hal ini menunjukkan bahwa data kedalaman masih masuk tolerasi standar IHO. Jadi, berdasarkan uji ketelitian yang dilakukan, data kedalaman pengukuran Sungai Serang masuk dalam Orde 1.

\section{Hasil Analisis Batimetri Sungai Serang}

Sebagai unsur alam yang mungkin membawa dampak pada pedangkalan Pelabuhan Tanjung Adikarto, Sungai Serang juga memerlukan pemantauan. Penelitian ini juga menghasilkan kedalaman atau batimetri dari Sungai Serang. Kedalaman Sungai Serang ditunjukkan pada Gambar 8.

Sesuai Gambar 8., area yang dalam ditunjukkan dengan warna biru muda dan area dangkal ditunjukkan warna biru tua. Kedalaman di hilir Sungai Serang memiliki kedalaman 0,9 meter sd. 1,8 meter.

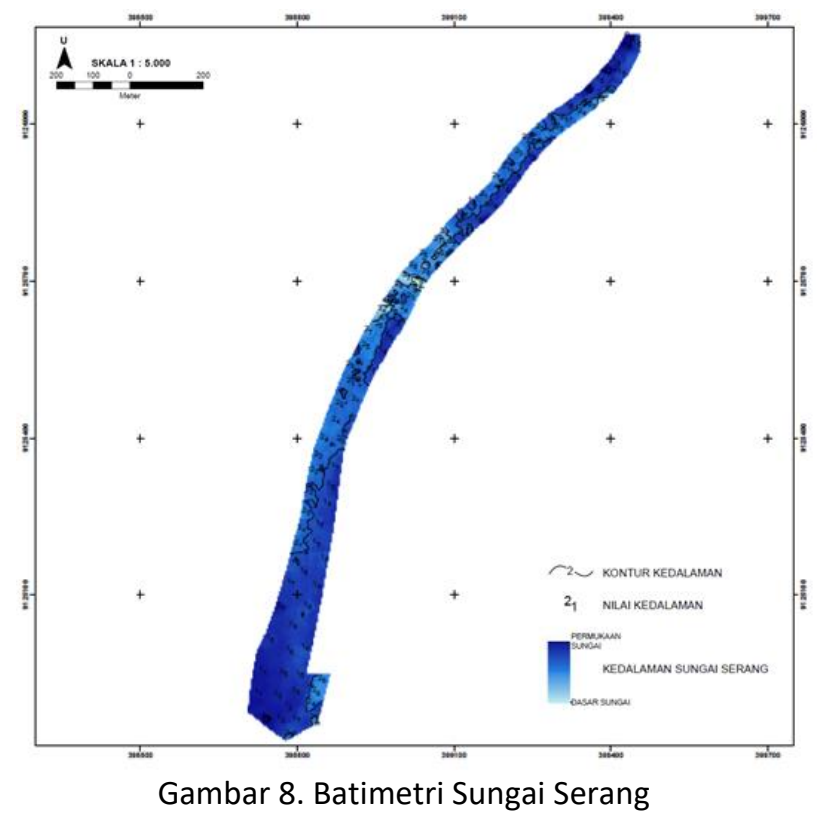

Untuk mengetahui sedimentasi Sungai Serang secara detil diperlukan adanya data batimetri multi-tahun. Namun, dalam penelitian ini dilakukan analisis profil memanjang dan melintang Sungai Serang untuk menginterpolasi area penumpukan sedimen di sekitar Sungai Serang dan Pelabuhan Tanjung Adikarto.

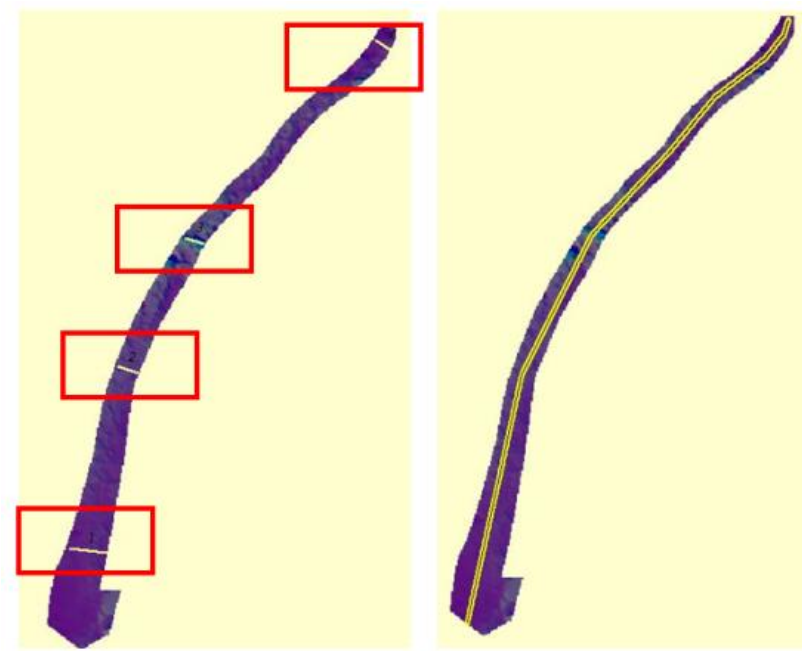

Gambar 9. Lokasi Area Profil Melintang dan Memanjang Sungai Serang

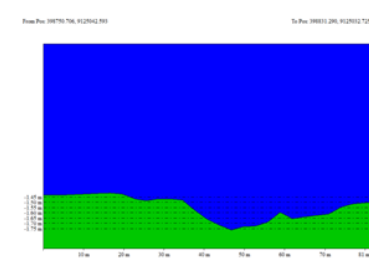

(a)

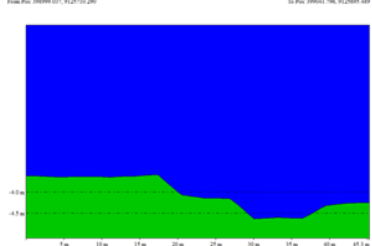

(b)

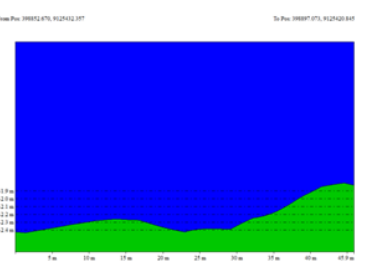

(b)

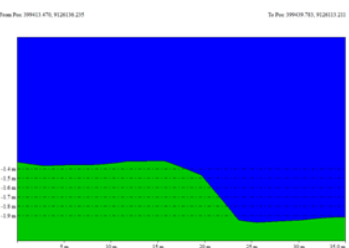

(d)
Gambar 10. Profil Melintang Sungai Serang

Berdasarkan profil melintang ke arah Barat-Timur pada Gambar 9. dan 10., Sungai Serang memiliki topografi menyerupai huruf " $\mathrm{V}$ " dengan kedalaman paling dalam adalah dibagian tengah sungai. Hal ini sesuai dengan profil kedalaman sebuah sungai. Lokasi penumpukan sedimen diinterpolasi dari daerah dengan kedalaman yang dangkal. Berdasarkan profil melintang tersebut, area penumpukan sedimen sungai serang berada disekitar tepi sungai. 


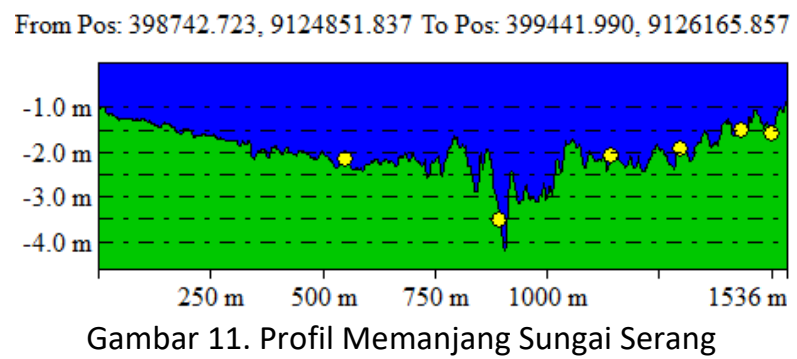

Gambar 11. merupakan gambaran profil memanjang Sungai Serang dari Utara ke Selatan. Kedalaman Sungai Serang mengalami penurunan di sekitar area $500 \mathrm{~m}$ dari pintu masuk pelabuhan. Kedalaman semakin dalam seiring mendekati pintu pelabuhan. Hal ini dapat mengindikasikan bahwa Sungai Serang juga mempengaruhi sedimentasi di sekitar pintu masuk Pelabuhan Tanjung Adikarto.

\section{Hasil Analisis Pengembangan Infrastruktur Yogyakarta}

Berdasarkan kajian yang telah dilakukan, masalah sedimentasi area Sungai Serang dan Pelabuhan Tanjung Adikarto dapat disebabkan oleh adanya sedimen yang terbawa oleh arus Sungai Serang dan terperangkap di sekitar pintu masuk kolam pelabuhan. Selain itu, kondisi breakwater yang ada dan ombak pantai selatan yang besar memungkinkan sedimen terjebak dalam kolam pelabuhan. Gambaran lokasi breakwater ditunjukkan Gambar 12.

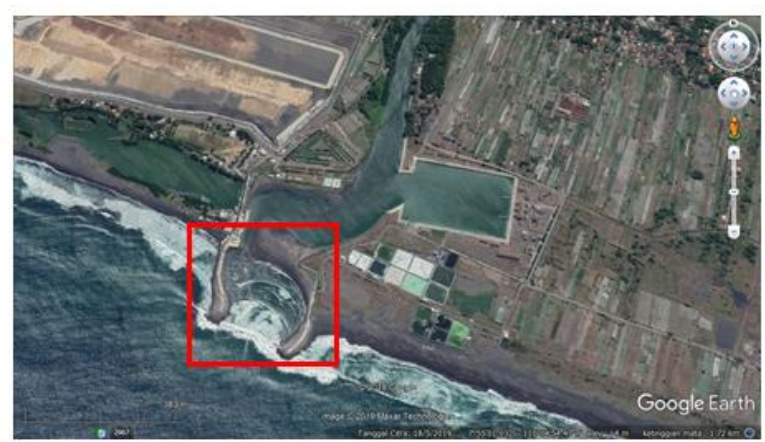

Gambar 12. Gambaran Lokasi Breakwater

Lokasi breakwater dan besarnya ombak pantai selatan dimungkinkan menjadi faktor penyebab terjadinya proses sedimentasi yang terjadi secara terus menerus. Redesign area breakwater Pelabuhan Tanjung Adikarto yang mempertimbangkan arah arus sedimentasi Sungai Serang maupun pergerakan sedimen di bibir pantai dapat dilakukan sebagai upaya dalam pengembangaan infrastruktur Yogyakarta, khususnya di area Sungai Serang dan Pelabuhan Tanjung Adikarto. Namun, masih diperlukan kajian lebih lanjut mengenai desain breakwater Pelabuhan Tanjung Adikarto tersebut.

\section{KESIMPULAN}

Kesimpulan yang dapat diambil dari hasil penelitian ini adalah sebagai berikut:

- Pasang surut laut masih mempengaruhi dinamika air Sungai Serang hingga jarak sekitar $1 \mathrm{~km}$ dari area breakwater Pelabuhan Tanjung Adikarto.

- Berdasarkan uji ketelitian standar IHO, data kedalaman pengukuran Sungai Serang masuk dalam Orde 1.

- Kedalaman hilir Sungai Serang memiliki kedalaman 0,9 meter s.d. 1,8 meter.

- Profil kedalaman Sungai Serang semakin dangkal mendekati pintu masuk Pelabuhan Tanjung Adikarto.

- Berdasarkan profil melintang dan memanjang, sedimentasi Sungai Serang berada di area tepi sungai dan disekitar pintu masuk Pelabuhan Tanjung Adiakrto.

- Kondisi breakwater dan sedimentasi Sungai Serang di sekitar area pintu masuk pelabuhan dapat menjadi salah satu penyebab masalah pengembangan infrastruktur di Pelabuhan Tanjung Adikarto.

\section{UCAPAN TERIMA KASIH}

Terimakasih diucapkan kepada seluruh anggota tim penelitian dosen muda UGM 2019 yang telah membantu dalam penelitian, serta kepada PT Sharp Mapping dan PT Geo Survei Persada atas kerjasama dalam menunjang peralatan pengukuran.

\section{DAFTAR PUSTAKA}

Arifin, L., \& Rachmat, B. (2011). Abrasi Pantai dan Pendangkalan Kolam Pelabuhan Jetty Pertamina Balongan, Indramayu melalui Analisis Pasang Surut, Angin dan Gelombang. Jurnal Geologi Kelautan Volume 9, No 1.

Cahyono, B. K. (2015). Perhitungan Volume Dan Sebaran Sedimentasi Waduk Sermo Berdasarkan Kondisi 
Awal Pembangunan Dan Keadaan Terkini Di Tahun 2016.

Cahyono, B. K. (2017). Perhitungan Kecepatan Sedimentasi Melalui Pendekatan Usle Dan Pengukuran Kandungan Tanah Dalam Air Sungai Yang Masuk Ke Dalam Waduk Sermo. Jurnal Nasional Teknologi Terapan Vol 1. No. 1.

Dunbabin, M. (2009). An Autonomous Surface Vehicle for Water Quality Monitoring. Australasian Conference on Robotics and Automation.

Febribusmadian, Purwanto, \& Hariadi. (2012). Studi Pola Arus dan Sedimentasi di dekat Breakwater Bagian Luar Kolam Labuh Pelabuhan Tanjung Emas Semarang. Journal of Oceanography, vol 1, no 2.

IHO. (1998). IHO Hydrographic Surveyi 4 Edition, Special Publication No 4. International Hydrographic Organization.

Pratomo, D. G., Froditus, N. O., \& Pribadi, C. B. (2019). Simulasi Tiga Dimensi Pola Arus dan Distribusi Sedimen di Perairan Cilacap sebagai Evaluasi terhadap Kondisi Dermaga. Surabaya: Geoid Geomatika ITS.

Pratomo, D. G., Hutanti, K., \& Khomsin. (2019). Analisis Pola Sebaran Sedimen Untuk Mendukung Pemeliharaan Kedalaman Perairan Pelabuhan menggunakan Pemodelan Hidrodinamika 3D (Studi Kasus: Pelabuhan Tanjung Perak, Surabaya). Surabaya: Geoid Geomatika ITS.

Siry, H. Y. (2011). Studi Sebaran Sedimen Dasar dan Pendangkalan di Pelabuhan Minyak (Oil Wharves) PT. Caltex Pacific Indonesia Dumai, Riau Pasca Pengerukan 1990. Widyariset.

SNI. (2010). SNI Survei Hidrografi Menggunakan Single Beam Echosounder. Jakarta: Badan Standarisasi Nasional.

Yuwono, Y., Pratomo, D. G., \& Al-Azhar, I. M. (2018). Analisis Posisi Kerangka Kapal Terhadap Keselamatan Alur Pelayaran Menggunakan Multibeam Echosounder (Studi Kasus: Alur Pelayaran Barat Surabaya). Surabaya: Geoid Geomatika ITS. 